\title{
Fundamentalisme Islam: Sejarah dan Gerakan
}

\author{
Yusdani
}

The fundamentalism of Islam emerges because of two factors- either external factor or internal factor. The external factor that causes appearing of the fundamentalism of Islam covering the fact that Muslim world faces the challenge of modernism, secularism and westernize tend to marginalize the religion (Islam) position in respective Muslim society. Whereas the internal factor includes the phenomena of religious particularly the moral decadence that happens in Muslim society. Besides, according to some reseacher's analyse regarding the emerging of the fundamentalism of Islam indicates that muslim can not answer the challenge of modernity creatively and they interpret the basic doctrine of Islam rigidly and textually that not in accordance with recent situation. In other word, they do not perceive Islam by using contextual interpretation.

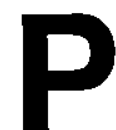

emikiran muslim kontemporer muncul dilatarbelakangi oleh kemunduran dan kerapuhan dunia Islam yang disebabkan oleh faktor-faktor internal yang kemudian melahirkan gerakan pembaruan dan pemurnian; masuknya imperialisme Barat ke dunia Islam yang melahirkan penjajahan Barat sehingga membangkitkan perlawanan Islam, dan keunggulan Barat dalam bidang ilmu pengetahuan, teknologi dan organisasi.' Salah satu bentuk gerakan pemikiran muslim yang muncul sebagai jawaban terhadap baik problema internal maupun penetrasi Barat adalah "fundamentalisme" Islam.

"Fundamentalisme" merupakan suatu istilah yang relatif baru dalam khazanah peristilahan Islam. ${ }^{2}$ Sebagian besar orang yang memakai istilah 'fundamentalisme' dan 'fundamentalis' seolah-olah tidak begitu memperdulikan konteks khusus Kristen, di mana istilah-istilah ini muncul. ${ }^{3}$ Secara

'Munawir Sjadzali, Islam dan Tata Negara: Ajaran, Sejarah dan Pemikiran (Jakarta: UI Press, 1991), h.115.

2Azyumardi Azra, Pergolakan Pemikiran Islam dari Fundamentalime, Modernisme Hingga Post-Modemism (Jakarta: Paramadina, 1996), h. 107.

${ }^{3}$ Riffat Hassan, "The Burgeoning of Islamic Fundamentalism: Toward and Understanding of Phenomenon", dalam norman J. Cohen (ed.), The fundamentalis Phenomenon, A View From Within, A Response From Without. ( Michigan: William B. Eerdmans Publishing Company, 1990), h.158. 
historis penggunaan istilah ini berkaitan dengan kebangkitan fundamentalisme dalam gereja Protestan, khususnya di Amerika Serikat. ${ }^{4}$

Kalangan muslim tertentu berkeberatan dengan penggunaan istilah 'fundamentalisme", terutama atas dasar konteks historis istilah tersebut dengan yang berkaitan "fundamentalisme Kristen". Karena itu, sebagian mereka menggunakan istilah usuliyyun untuk menyebut "orang-orang fundamentalis", yakni mereka yang berpegang kepada fundamen-fundamen pokok Islam sebagaimana terdapat dalam Alquran dan Hadis. Dalam kaitan ini pula digunakan istilah al-Usuliyyah al-Islamiyyah (fundamentalis Islam) yang mengandung pengertian; kembali kepada fundamen-fundamen keimanan; penegakan kekuasaan politik ummah, dan pengukuhan dasar-dasar otoritas yang absah (syariyyah al-hukm). Formulasi ini, seperti terlihat, menekankan dimensi politik gerakan Islam, ketimbang aspek keagamaannya. ${ }^{5}$

Terdapat sejumlah istilah lain dalam bahasa Arab, yang digunakan kalangan fundamenalis Islam untuk mengacu pada kelompok atau gerakan mereka. Yang terpenting di antaranya adalah; islamiyyun (kaum Islamis), asliyyun (kaum otentik, asli), dan salafiyyun (pengikut para sahabat utama). Sedangkan istilah muta'assib digunakan kalangan non-fundamentalis untuk menunjuk kelompok militan yang tidak enggan menggunakan kekerasan. Selain itu digunakan pula istilah-istilah mutaharif untuk menyebut ekstrimis. Dari semua istilah-istilah ini, yang paling lazim digunakan tentu saja adalah istilah usuliyyun (kaun fundamentalis) dan al-usuliyyah al-islamiyyah (fundamentalis Islam). ${ }^{6}$

Kata fundamentalis bila dilihat dari kacamata Barat memang tampak menakutkan dan seram. Sebagaimana ketika Barat memaknai dan mengekspresikan kata jihad,
Kebangkitan Islam, Gerakan Islam dan lain-lain. Padahal, fundamentalis tersebut menurut ilmuwan politik John L Esposito, mempunyai tiga arti. Pertama, fundamentalis adalah orang-orang yang menghendaki agar kembali ke kepercayaan dasar atau dasardasar suatu agama. Dalam arti yang terbatas, hal itu dapat mencakup semua orang Islam yang menerima Al-Quran sebagai firman Tuhan dan Sunnah sebagai model hidup yang normatif. Kedua, fundamentis(me) yang pengertiannya dipengaruhi oleh Protestanisme Amerika. Dalam Webster's Ninth New Collegiate Dictionary, fundamentalisme diartikan sebagai sebuah gerakan protestanisme abad keduapuluh yang menafsirkan injil secara literal sebagai hal yang fundamental bagi kehidupan dan ajaran Kristen. Di sini istilah fundamentalis adalah mengandung hinaan dan bermakna statis, kemunduran dan ekstrim. Ketiga, kata Esposito, fundamentalis sering disejajarkan dengan aktifitas politik, ekstremisme, fanatisme dan anti Amerikanisme.?

\section{Sejarah dan Gerakan Fundamentalisme Islam}

Penggunaan istilah "fundamentalisme" —dalam konteks agama Kristen' di Amerika Serikat- sebagai agama pengganti "yang lebih rendah" dibandingkan dengan agama-

${ }^{4}$ Azyumardi Azra, "Fundamentalisme Kristen: Fenomena Kebangkitan Agama di AS," Kompas 6 Maret 1987.

"Elsayed Eishahed, "What is the Challenge of Contemporary Islamic Fundamentalism?" dalam Hans Kung \& Jurgen Moltmann (eds.) Fundamentalism as a Ecumenical (London 1992), h. 62-63.

'Azyumardi Azra, Pergolakan, h.109.

${ }^{7} \mathrm{H}$. Ahmad Sumargono, Saya Seorang Fundamentalis, (Bogor: Global Cita Press, 1999), h. iv. 
agama yang sudah ada. Fundamentalisme muncul setelah "agama-agama yang terorganisasi" (“organized religions") gagal memberikan respons yang memadai dan kreatif terhadap tantangan dunia modern. ${ }^{8}$

Penggunaan Istilah "fundamentalisme" dalam Islam oleh kalangan Barat mulai populer berbarengan dengan terjadinya Revolusi Islam Iran pada 1979, yang memunculkan kekuatan Muslim Syi'ah radikal dan fanatik yang siap mati melawan the great satan, Amerika Serikat. Meski Istilah fundamentalisme Islam baru populer setelah peristiwa historis ini, namun dengan mempertimbangkan beberapa prinsip dasar dan karakteristik, maka fundamentalisme Islam telah muncul jauh sebelum itu. ${ }^{9}$

Setelah Revolusi Islam Iran, istilah fundamentalisme Islam digunakan untuk menggeneralisasi berbagai gerakan Islam yang muncul dalam gelombang yang sering disebut sebagai "kebangkitan Islam" (Islamic revival). Memang, dalam beberapa dasawarsa terakhir terlihat gejala "kebangkitan Islam", yang muncul dalam berbagai bentuk intensifikasi penghayatan dan pengamalan Islam, yang diikuti dengan pencarian dan penegasan kembali nilai-nilai Islam dalam berbagai aspek kehidupan. Tetapi menyebut semua gejala intensifikasi itu sebagai "fundamentalisme Islam" jelas merupakan simplikasi yang distortif. ${ }^{10}$.Dalam kaitan ini, John L. Esposito mengecam pedas pandangan sejumlah Orientalis tentang fundamentalis di kalangan Islam. Esposito mengatakan sejumlah Orientalis telah memahami fundamentalis Islam sebagai kalangan yang memahami ajaran secara literal dan akan kembali ke model kehidupan 14 abad yang lalu dalam segala bentuk dan ekspresinya, padahal kenyataannya tidak demikian. Esposito kemudian menulis:

"Indeed many fundamentalist leaders have had the best education, enjoy responsible positions in society, and are adept at harnessing the latest technology to propagate their views and create viable modern institutions such as schools, hospitals, and social service agencies."

Fundamentalisme Islam dapat dikatakan merupakan bentuk ekstrem dari gejala "revivalisme". Jika revivalisme dalam bentuk intensifikasi keislaman- lebih berorientasi "ke dalam" (inward oriented) -dan karenanya sering bersifat individual- maka pada fundamentalisme, intensifikasi itu juga di arahkan ke luar (outward oriented). Tegasnya, interisifikasi bisa berupa sekadar peningkatan attachment pribadi terhadap Islam —dan sebab itu sering mengandung dimensi esoteris - tetapi fundamentalisme menjelma dalam komitmen yang tinggi tidak hanya untuk mentransformasi kehidupan individual, tetapi sekaligus kehidupan komunal dan sosial. Oleh karena itu, fundamentalisme Islam juga sering bersifat eksoteris, yang sangat menekankan batasbatas kebolehan dan keharaman berdasarkan figh ("halal-haram).12

Fundamentalisme Islam dengan demikian, tidaklah sepenuhnya baru, sebelum munculnya fundamentalisme kontemporer terdapat gerakan yang mungkin dapat disebut sebagai prototype gerakangerakan fundamentalisme yang muncul dalam masa-masa lebih belakangan. Oleh karena itu, untuk menghindari kekeliruan

${ }^{8}$ Nurcholish Madjid, Islam: Doktrin dan Peradaban (Jakarta: Yayasan Wakaf Paramadina, 1992),h. 586.

${ }^{9}$ Azyumardi Azra, Pergolakan, h. 107.

${ }^{10} / \mathrm{bid}$.

"John L. Esposito, The Islamic Threat: Myth or Reality (Oxford: Oxford University Press, 1992),h.7

${ }^{12}$ Ibid. h. 107-108. 
Topik: Fundamentalisme Islam: Sejarah dan Gerakan, Yusdani

dalam memahami fundamentalisme Islam di atas ada baiknya gerakan fundamentalisme dibagi menjadi dua tipologi: pramoderen, dan kontemporer yang dapat pula disebut neo-fundamentalisme. Fundamentalisme pra-moderen muncul disebabkan situasi dan kondisi tertentu di kalangan umat Muslimin sendiri. Karena itu, kaum muslim sendiri lebih genuine dan inward orientedberorientasi. Pada pihak lain, fundamentalisme kontemporer bangkit sebagai reaksi terhadap penetrasi sistem dan nilai sosial, budaya, politik dan ekonomi Barat, baik akibat sebagai kontak langsung dengan Barat maupun melalui pemikir Muslimtegasnya kelompok modernis, sekularis, dan westernis-atau rejim pemerintahan Muslim yang menurut kaum fundamentalis merupakan perpanjangan mulut dan tangan Barat. ${ }^{13}$

Kebangkitan fundamentalisme dalam Islam, sebenarnya merupakan reaksi keras atas pemikiran liberalisme (modernisme) Islam. Fazlur Rahman dalam karangannya; "Islam: Challenges and Opportunities, ${ }^{14}$ menggambarkan reaksi-reaksi (kalangan fundamentalis) terhadap kaum liberal Islam (atau sebutan lain untuk kaum modernis, baik yang awal maupun yang baru, berarti neo-modernis). Gerakan fundamentalis ini, yang disebut Rahman dengan gerakan revivalis, berawal dengan hadimya "gerakan revivalis pra-modernis." Terutama, lewat gerakan Ibn 'Abd al-Wahab (Wahabiyah), yang oleh Rahman digambarkan sebagai "denyut pertama kehidupan Islam," setelah Islam mengalami kemerosotan beberapa abad sebelumnya. ${ }^{15}$

Untuk pertama kali setelah lima abad sebelumnya, Ibn Taymiyah (w. 1328) berjuang sendirian, gerakan inipun mengambil suatu jalan radikal. Yakni, mempersoalkan tradisi Islam yang hidup dengan "jalan" mengkonfrontasikannya pada sumber-sumber asli Islam, yaitu Alquran dan Sunnah Nabi saw. Bersamaan dengan gerakan Wahabi ini, berkembang pula Sanusiah di Afrika Utara, Fulaniah di Afrika Barat dan beberapa gerakan di india. Gerakan ini oleh Fazlur Rahman dicirikan dengan: ${ }^{16}$

Pertama, bentuk keprihatinan yang mendalam atas kemerosotan moral dan sosial masyarakat Muslim.

Kedua, menghimbau kaum Muslim untuk kembali kepada Islam yang orisinal, yang "murni" (salafiyah), dengan meninggalkan takhayultakhayul yang ditanamkan dalam Sufisme populer, termasuk gagasan tentang kemapanan dan finalitas mazhab-mazhab hukum tradisional. Gerakan ini juga berusaha melakukan ijtihad, khususnya untuk merenungkan makna pesan orisinal Islam itu, atau apa yang menjadi prasyarat "Islam murni."

Ketiga, menghimbau untuk membuang beban yang menghancurkan, berupa pandangan tentang takdir dari "agama rakyat," dan teologi Asy'ariyah yang berpengaruh dimana-mana.

Keempat, perlunya melakukan pembaruan yang dipelopori kaum revivalis ini melalui jihad, kalau itu dianggap perlu.

Apa yang menarik dari usaha kembali kepada monoteisme murni (tauhid) dari gerakan Wahabiyah ini- adalah tekanannya

${ }^{13}$ Azyumardi Azra, Pergolakan, h. 111.

${ }^{14}$ Lihat Fazlur Rahman, "Islam:Challenges and Opportunities," dalam Alford T. Welch dan Pierre Cachia (ed.), Islam and Past influence and Present Challenge, (London: Edinburgh University Press, 1979).

${ }^{15}$ Budhy Munawar-Rachman, Islam Pluralis, h. 433.

${ }^{16} / \mathrm{bid}$. 
Topik: Fundamentalisme Islam: Sejarah dan Gerakan, Yusdani

untuk berani berpikir sendiri atau melakukan ijtihad. Dengan ijtihad, berarti tercermin sikap penolakan kepercayaan buta kepada otoritas, yang dalam literatur hukum diistilahkan taqlid. Hal ini berarti bahwa gerakan revivalis awal ini, tidaklah sepenuhnya anti-intelektual. Sehingga, gerakan ini sebenarnya juga tidak bisa disebut "fundamentalis," karena kaum modemis juga belum muncul. Justru serangan mereka adalah melulu kepada praktik keagamaan rakyat. ${ }^{17}$

Gagasan-gagasan pokok mengenai fundamentalisme Kristen berintikan: pertama, mempertentangkan pernyataan Allah dengan akal manusia; Kedua, mempertentangkan Kitab Suci (Sacred Text) dengan ilmu pengetahuan; Ketiga, mengamankan Kitab Suci terhadap kritik kitab suci, dengan ajaran bahwa Kitab Suci yang "tidak bisa salah"; dan Keempat, mencap orang yang tidak sependapat dengan itu semua sebagai "Kristen yang tidak benar."18

Jika gagasan-gagasan dasar fundamentalisme Kristen di atas diterapkan ke dalam konteks Islam ${ }^{19}$ maka hasilnya adalah:

Pertama, masalah mempertentangkan pernyataan Allah dengan akal manusia, maka sejak awal, Islam justru sangat mendorong umatnya untuk merenungkan firman Allah dengan akal dan sekaligus juga memperhatikan alam ini sebagai tandatanda kekuasaan Tuhan (the sign of God).

Kedua, masalah mempertentangkan Kitab Suci (Sacred Text) dengan ilmu pengetahuan, justru karena akal diberikan tempat dalam kesadaran beragama, maka dalam perkembangan dewasa ini, apresiasi terhadap ilmu pengetahuan malah begitu berkembang dalam Islam. Bahkan, orang Islam sangat menyukai dengan ilmu pengetahuan itu. Nabi saw sendiri bersabda, "tuntutlah ilmu (pengetahuan), meskipun sampai ke negeri Cina" (Hadis). Apalagi, jika ilmu pengetahuan yang di- pelajari itu, justru ikut membantu dalam memperjelas keimanan kaum muslimin kepada Tuhan, maka hal itu justru diperintahkan.

Ketiga, masalah Kitab Suci (berarti Alquran) "tidak bisa salah," maka dalam konteks Islam, statemen ini justru merupakan pandangan umum kaum Muslim. Sehingga, kalau definisi fundamentalisme Kristen ini diterapkan kepada Islam, maka jelas-seperti dikatakan Bernard Lewis, orientalis terkemuka yang ahli islam-, "sikap semua kaum Muslim terhadap teksteks Alquran, paling tidak pada prinsipnya adalah fundamentalis. ${ }^{20}$

Keempat, masalah mencap orang yang tidak sependapat dengan itu semua sebagai "Islam yang tidak benar," kiranya hal ini bersifat relatif saja. Sebab, kesadaran adanya perbedaan mazhab (aliranaliran keagamaan) amat menonjol sepanjang sejarah Islam, sehingga paham inklusivisme intra-agama, kurang-lebih hidup dalam masyarakat. ${ }^{21}$

Sebenarnya istilah "fundamentalisme" itu sendiri-seperti dikatakan Chandra Muzaffar-untuk pertama kalinya ditransfer ke Asia Barat oleh pers Amerika, dalam rangka menggambarkan protes-protes yang menentang Syah Iran pada akhir tahun 70-

${ }^{17}$ Fazlur Rahman, "Islam Challenge".

"Djaka Soetapa, "Asal-Usul Gerakan Fundamentalisme," dalam Ulumul Qur'an, No. 3, Vol. IV, 1993.

${ }^{19}$ Budhy Munawar-Rachman," Fundamentalisme Islam Sebagai Reaksi Terhadap Liberalisme Islam," dalam Jurnal Teologi dan gereja, Penuntun, Vol. 3 No. 10, Januari 1997, h. 173-192.

${ }^{20}$ Bernard Lewis, The Political Language of Islam (Chicago: University of Chicago Press, 1988), h. 117.

${ }^{21}$ Budhy Munawar-Rachman, Is/am Pluralis Wacana Kesetaraan Kaum Beriman (Jakarta: Paramadina, 2001), h. 425. 
an. ${ }^{22}$ Karena itu dalam Islam, istilah fundamentalisme ini selalu berkonotasi pejoratif, yakni digunakan untuk menyatakan atau menyebut "lawan," bukan untuk menyebut diri kaum muslimin sendiri. Cap-cap yang diberikan dengan istilah "fundamentalis" ini adalah: reaksioner, otoriter, tidak masuk akal, literalis, tidak kosmopolit, anti modem, mungkin juga paranoid. Meskipun begitu, istilah "fundamentalisme" pada fenomena Islam- dalam arti sosiologis, tetap dapat digunakan, asal dengan hati-hati. Karena itu, untuk memahami fenomena fundamentalisme dalam Islam, diperlukan memberikan perhatian pada konteksnya. Secara ringkas, fundamentalisme dalam Islam merupakan reaksi keras atas usahausaha kalangan liberal Islam dalam rangka memberikan tafsiran baru atas Alquran. ${ }^{23}$ Penting sekali untuk memahami aspek historis liberalisme Islam tersebut, agar dapat dipahami latarbelakang responrespon kaum fundamentalis atas ide-ide kaum liberal. ${ }^{24}$

\section{Prinsip dan Ajaran Fundamentalisme Islam}

Untuk lebih memperjelas pemahaman terhadap fenomena fundamentalis Islam, kerangka pemikiran yang diberikan sosiolog agama, Marty, ${ }^{25}$ dengan beberapa modifikasi, agaknya cukup relevan diterapkan untuk melihat gejala "fundamentalisme Islam". Prinsip pertama fundamentalime adalah "oppositionalism" (paham perlawanan). Fundamentalisme dalam agama manapun mengambil bentuk perlawanan -yang bukannya tak sering bersifat radikalterhadap ancaman yang dipandang membahayakan eksistensi agama, apakah dalam bentuk modemitas atau modernisme, sekularisasi, dan tata nilai Barat pada umumnya. Acuan dan tolok ukur untuk menilai tingkat ancaman itu tentu saja adalah kitab suci, yang dalam kasus fundamentalisme Islam adalah Alquran, dan pada batas tertentu Hadis. ${ }^{26}$

Prinsip kedua adalah penolakan terhadap hermeneutikà. Dengan kata lain, kaum fundamentalis menolak sikàp kritis terhadap teks dan interpretasinya. Teks Alquran harus dipahami secara literal-? sebagaimana adanya, karena nalar dipandang tidak mampu memberikan inter-. pretasi yang tepat terhadap teks. Meski' bagian-bagian tertentu dari teks kitab suci boleh jadi kelihatan bertentangan satu sama lain, nalar tidak dibenarkan melakukan semacam "kompromi" dan menginterpretasikan ayat-ayat tersebut. ${ }^{27}$

Prinsip ketiga adalah penolakan terhadap pluralisme dan relativisme. Baigi kaum fundamentalisme, pluralisme merupakan hasil dari pemahaman yang keliru terhadap teks kitab suci. Pemahaman dan sikap keagamaan yang tidak selaras dengan pandangan kaum fundamentalis merupakan bentuk dari relativisme keagamaan, yang terutama muncul tidak hanya dari intervensi nalar terhadap teks

${ }^{22}$ Chandra Muzaffar, "Fundamentalist Fallacy," dalam FEER, 23 April 1992, h.23.

${ }^{23}$ Fazlur Rahman, "Islam: Challenges and Opportunities", dalam Alford T. Welch and Pierre (ed.) Islam: Past Influence and Present Challenge, (London: Edinburgh University Press, 1979).

24Jalaluddin Rakhmat, "Fundamentalisme Islam: Mitos dan Realitas," dalam Prisma, Nomor Ekstra, 1984. Rifyal Ka'bah, "Modernisme dan Fundamentalisme Ditinjau dari Konteks ' Islam", dalam Ummul Quran, No. 3, vol. IV, 1993.

25Martin E. Marty," What is Fundamentalism?: Theological Perspective", dalam Kung \& Moltmann (eds.), Fundamentalism, h. 3-13. ${ }^{26}$ Azyumardi Azra, Pergolakan, h. 109. ${ }^{27}$ ibid, h. 110. 
kitab suci, tetapi juga karena perkembangan sosial kemasyarakatan yang telah lepas dari kendali agama. ${ }^{28}$

Prinsip keempat adalah penolakan terhadap perkembangan historis dan sosiologis. Kaum fundamentalis berpandangan, bahwa perkembangan historis dan sosiologis telah membawa manusia semakin jauh dari doktrin literal kitab suci. Perkembangan masyarakat dalam sejarah dipandang sebagai " as it should be" bukan "as it is". Dalam kerangka ini, adalah masyarakat yang menyesuaikan perkembangannya- kalau perlu secara kekerasan--dengan teks kitab suci, bukan sebaliknya, teks atau penafsirannya yang mengikuti perkembangan masyarakat. Karena itulah, kaum fundamentalis bersifat a-historis dan a-sosiologis; dan tanpa peduli bertujuan kembali kepada bentuk masyarakat "ideal"-_bagi kaum fundamentalis Islam seperti pada zaman kaum Salafyang dipandang mengejawantahkan kitab suci secara sempurna. ${ }^{29}$

Seiring dengan kecenderungan penafsirannya terhadap doktrin yang bercorak rigid dan literalis, fundamentalisme memandang bahwa corak pengaturan doktrin bersifat total dan serba mencakup. Tidak ada masalah-masalah yang berhubungan dengan kehidupan manusia di dunia ini yang luput dari jangkauan doktrin yang serba mencakup itu. Karena itu, ijtihad dengan sendirinya dibatasi hanya kepada masalah-masalah dimana doktrin tidak memberikan petunjuk dan pengaturan sampai detail-detail persoalan. ${ }^{30}$

Sesuai dengan kecenderungan corak penafsiran di atas, fundamentalisme memandang preseden zaman awal Islam adalah mengikat secara keseluruhan. Hal ini berarti bahwa preseden itu bukan hanya mengikat dalam prinsip, melainkan juga dalam perincian-perinciannya. Fundamentalisme berpendapat bahwa orang-orang yang hidup di zaman awal lebih memahami maksud-maksud doktrin. Zaman awal Islam, yaitu zaman Nabi dan para sahabat, adalah zaman ideal yang wajib diwujudkan di segala zaman. Sesuai dengan pandangan ini, fundamentalisme mamandang konsensus (ijma') zaman sahabat Nabi adalah konsensus yang mengikat generasi-generasi kaum Muslim hingga akhir zaman. Konsensus demikian tidak dapat diubah oleh berbagai konsensus yang dibuat oleh generasi yang hidup setelah mereka. Kaum fundamentalis juga - berbeda dengan kaum modernis - pada umumnya memberikan apresiasi yang tinggi terhadap warisan sejarah dan tradisi Islam di zaman awalawal Islam. Juga, pada tradisi pemikiran Islam yang diwariskan oleh para ulama di masa lampau yang dipandang mempunyai otoritas. ${ }^{31}$

Sesuai dengan pandangan-pandangan di atas, fundamentalisme cenderung memandang negatif dan pesimis kepada pluralisme. Masyarakat cenderung dilihat secara "hitam-putih", yaitu antara masyarakat Islami yang meyakini dan mengamalkan doktrin secara kafah (menyeluruh) dengan masyarakat Jahiliah yang tidak meyakini dan mengamalkannya. Sejarah manusia cenderung untuk dilihat sebagai sejarah pertentangan antara dua golongan masyarakat ini, yang disimbolkan dengan sejarah para Nabi dan para penentangnya. Dengan pembagian masyarakat pada dua golongan itu, maka hikmah tidak perlu dicari

${ }^{28} /$ bid,
${ }^{29} /$ bid, h. 110.
${ }^{30}$ Yusril lhza Mahendra, Modernisme dan Fundamentalisme dalam Politik Islam Perbandingan Partai Masyumi (Indonesia) dan Partai Jama'at -I-Islami (Pakistan) (Jakarta: Paramadina, 1999), h. 31-32.

${ }^{31}$ lbid. h. 32. 
dalam masyarakat-masyarakat yang telah "jelas" bersifat Jahiliah itu. Karena itu, fundamentalisme cenderung bersifat tertutup dari kemungkinan beradaptasi dan berakulturasi dengàn prestasi-prestasi peradaban yang telah dikembangkan oleh masyarakat lain. Memang, bagi fundamentalisme, manusia di dunia ini hanya dihadapkan kepada dua pilihan, manjadi "mu'min" atau menjadi "kafir". 32

Dalam konteks pandangan fundamentalisme Islam yang pesimis dan negatif terhadap pluralisme di atas, menurut tokoh yang dapat digolongkan "neo-modernis" muslim menggunakan istilah "fundamentalisme" dengan nada yang berbau sinisme dan kritik. Fazlur Rahman, misalnya, menyebut kaum fundamentalis muslim sebagai "orang-orang yang dangkal dan superfisial", "anti intelektual" dan pemikirannya "tidak bersumberkan kepada AlQur'an dan budaya intelektual tradisi Islam". 33

Fundamentalisme, di samping menyebarkan paham keagamaan yang telah "standard" (baku) dalam suatu agama tertentu, juga menyebarkan gagasangagasan yang "palsu dan bersifat menipu". Di masa sekarang, fundamentalisme telah menjadi "sumber kekacauan dan penyakit mental" yang baru dalam masyarakat. Akibat-akibat yang ditimbulkannya, jauh lebih buruk dibandingkan dengan masalah -masalah sosial yang sudah ada, seperti kecanduan minuman keras dan penyalahgunaan narkotika.

Bertitik-tolak dari penjelasan di atas jelaslah bahwa sesungguhnya pemikirpemikir fundamentalis yakin pada Islam sebagai agama yang menyeluruh, mencakup seluruh aspek kehidupan. Islam dipandang sebagai sistem, mencakup seluruh wilayah kultural. Tapi pemikirpemikir fundamentalis juga menekankan perbedaan dan pertentangan antara Islam dan Barat, dan yakin pada kebenaran Islam yang menghadapi tantangan Barat. ${ }^{34}$

Dalam wilayah politik, kaum fundamentalis cenderung menghindar dari setiap ide yang dipandang terbaratkan, dan karena itu dianggap tidak Islami. Dengan pemahaman atas Islam secara literal dan tekstual, kaum fundamentalis lebih berupaya mengembangkan konsep-konsep mereka sendiri dari perspektif Islam sebagai alternatif atas konsep-konsep Barat. ${ }^{35}$

Untuk kasus Indonesia, kemunculan fundamentalisme Islam dipengaruhi sebagian oleh faktor internasional, yaitu perkembangan fundamentalisme Islam di dunis Islam, dan oleh dinamika dialketis internal dalam tubuh umat Islam Indonesia itu sendiri. ${ }^{36}$

Ketidakmampuan dan ketidakefektifan gerakan-gerakan Islam yang mapan dalam melakukan. islamisasi di Indonesia, terutama di hadapan penguasa yang melakukan depolitisasi atas Islam dan deislamisasi politik dan berbagai aspek kehidupan lainnya telah melahirkan kelompok penentang dalam masyarakat Islam Indonesia. Mereka memandang revolusi sebagai pembenaran atas optimisme masa depan. Banyak dari kelompok-kelompok ini ditransformasikan .ke dalam kelompok sempalan, yang lewat sikap reaksioner, menantang penguasa, dan beberapa di antara mereka juga menantang kemapanan Islam dengan menawarkan semacam alternatif. ${ }^{37}$

\section{2 /bid.}

${ }^{33}$ Fazlur Rahman, Islam and Modernity: Transformation of an Intellectual Tradition, (Minneapolis: Bibliotheca, 1979), h.164

${ }^{34} \mathrm{M}$. Din Syamsuddin, Islam dan Politik Era Orde Baru (Jakarta: Logos Wacana Ilmu, 2001), h.140.

${ }^{35}$ /bid.

${ }^{36} /$ bid. h. 160.

${ }^{37}$ Ibid. 
Sejarah Islam di Indonesia masa Orde Baru telah menyaksikan kemunculan sejumlah kelompok sempalan, termasuk Islam Jamaah di Jawa Timur, Kelompok Islam Isa Bugis, Jamaah Tablig dan Jamaah Tanbih. Dua kelompok yang terakhir ini terutama tumbuh di Jakarta dan diimpor dari luar, masing-masing dari India dan Irak. Selain itu terdapat pula di kalangan generasi muda Islam lingkaran-lingkaran "Usrah" (arti harfiahnya, "keluarga"). ${ }^{38}$

Walaupun sebenarnya terpisah-pisah, usrah-usrah ini tersebut mempunyai slogan yang sama: Kembali ke Alquran dan al Sunnah. Slogan ini telah mendorong mereka mengorganisasikan studi-studi reguler intensif tentang keislaman, mengkaji dasardasarnya, mulai melaksanakannya dalam kehidupan sehari-hari. Kelompok-kelompok Usrah ini telah menjadikan masjid sebagai basis kegiatan mereka. Yang terpenting adalah Masjid Salman ITB, Masjid Salahuddin UGM, Masjid Arief Rahman Hakim UI, dan Masjid al-Gifari IPB. ${ }^{39}$

Di Era reformasi sekarang ini, bermunculan banyak kelompok muslim yang menamakan dirinya sebagai pembela Islam, Lasykar Jihad, kelompok Mujahidin, dan lainlain yang oleh kelompok muslim lainnya dituduh sebagai kelompok fundamentalisme. Terlepas apakah mereka dapat dinamakan demikian, tetapi yang jelas mereka mempunyai misi memberantas ketidakadilan dan penindasan yang berlangsung dalam kehidupan masyarakat.

\section{Penutup}

Sebagai penutup dari tulisan ini perlu dikemukakan bahwa perkembangan gerakan fundamentalisme Islam banyak dipengaruhi tidak hanya oleh kepemimpinan gerakan organisasi itu sendiri, tetapi juga oleh watak rezim penguasa, dan tidak kurang pula, oleh perkembangan-per- kembangan pada tingkat Dunia Muslim, khususnya yang melibatkan kekuatan Barat. Karena itu, tidak aneh, kalau seusai Revolusi Islam Iran, gerakan fundamentalisme radikal berkecambah di banyak wilayah Dunia Muslim. Hal yang sama juga terjadi menjelang dan sepanjang Krisis (Perang) Teluk 1991 yang bermula dengan invasi Irak terhadap Kuwait yang selanjutnya dicampuri kekuatan Barat yang dipimpin Amerika; gerakan fundamentalisme Islam radikal di berbagai negara Muslim kembali menemukan momentumnya. Peristiwa aksi Amerika dan Inggris memburu Osama bin Laden dan jaringan alQaida-nya di Afganistan sebagai akibat dari peristiwa hancumya Gedung WTC Selasa, 11 September 2001 yang lalu, dan peristiwa pembantaian rakyat Palestina oleh tentara Israel pada waktu akhir-akhir ini akan membangkitkan gerakan fundamentalisme Islam radikal dan jaringannya di berbagai negara muslim.

Bagaimana masa depan fundamentalisme Islam. Pernyataan ini sangat tidak mudah dijawab. Seperti terlihat, fundamentalisme, khususnya yang ekstrem dan militan, sepanjang sejarah tidak selalu berhasil. Jika sejarah adalah cermin, maka cukup sah bagi orang untuk bersifat skeptis terhadap masa depan fundamentalisme radikal.

\footnotetext{
${ }^{38} \mathrm{lbid}$. h.161.

${ }^{39} /$ bid. h.161-162.
} 


\section{Daftar Pustaka}

Azra, Azyumardi. 1996, Pergolakan Pemikiran Islam dari Fundamentalime, Modernisme Hingga PostModernisme. Jakarta: Paramadina.

-_- "Fundamentalisme Kristen: Fenomena Kebangkitan Agama di AS," Kompas, 6 Maret 1987.

Elshahed, Elsayed. 1992, "What is the Challenge of Contemporary Islamic Fundamentalism?" dalam Hans Kung \& Jurgen Moltmann (eds.) Fundamentalism as a Ecumenica. London.

Esposito, John L. 1992, The Islamic Threat: Myth or Reality. Oxford: Oxford University Press.

Hassan, Riffat. 1990, "The Burgeoning of Islamic Fundamentalism: Toward and Understanding of Phenomenon", dalam norman J. Cohen (ed.), The fundamentalis Phenomenon, A View From Within, A Response From Without. Michigan: William B. Eerdmans Publishing Company.

Husaini, Adian. 2001, Jihad Osama Versus Amerika, Jakarta: Gema insani Press.

Ka'bah, Rifyal.1993, "Modernisme dan Fundamentalisme Ditinjau dari Konteks Islam". dalam Ummul Quran, No. 3, vol. IV, 1993.

Lewis, Bemard.1988, The Political Language of Islam. Chicago: University of Chicago Press.

Mahendra, Yușril Ihza.1999, Modernisme dan Fundamentalisme dalam Politik Islam Perbandingan Partai Masyumi (Indonesia) dan Partai Jama'at -1Islami (Pakistan). Jakarta: Paramadina.
Madjid, Nurcholish.1992, Islam: Doktrin dan Peradaban, Jakarta: Yayasan Wakaf Paramadina.

Marty, Martin E." What is Fundamentalism? Theological Perspective", dalam Kung \& Moltmann (eds.), Fundamentalism.

Muzaffar, Chandra. "Fundamentalist Fallacy," dalam FEER, 23 April 1992.

Rachman, Budhy Munawar. 2001; Islam Pluralis Wacana Kesetaraan Kaum Beriman. Jakarta: Paramadina. . "Fundamentalisme Islam Sebagai Reaksi Terhadap Liberalisme Islam," dalam Jurnal Teologi dan Gereja, Penuntun, Vol. 3 No. 10, Januari 1997.

Rahman, Fazlur. 1979, "Islam: Challenges and Opportunities", dalam Alford T. Welch and Pierre (ed.) Islam: Past Influence and Present Challenge. London: Edinburgh University Press.

. 1979, Islam and Modernity: An Intellectual Transformation. Minneapolis: Bibliotheca Islamica.

Rakhmat, Jalaluddin. "Fundamentalisme Islam: Mitos dan Realitas," dalam Prisma, Nomor Ekstra, 1984.

Soetapa, Djaka. "Asal-Usul Gerakan Fundamentalisme," dalam Ulumul Qur'an, No. 3, Vol. IV. 1993.

Sumargono, H. Ahmad. 1999, Saya Seorang Fundamentalis. Bogor: Global Cita Press.

Sjadzali, Munawir. 1991, Islam dan Tata Negara: Ajaran, Sejarah dan Pemikiran. Jakarta: UI Press.

Syamsuddin, M. Din. 2001, Islam dan Politik Era Orde Baru. Jakarta: Logós Wacana llmu. 